\title{
ПРОБЛЕМА ФОРМУВАННЯ КУЛЬТУРОЛОГІЧНОЇ КОМПЕТЕНТНОСТІ СТУДЕНТІВ БАКАЛАВРАТУ - МАЙБУТНІХ ЕКОНОМІСТІВ
}

У статті представлено передумови формування культурологічної компетентності студентів

бакалаврату - майбутніх економістів. Підкреслюється необхідність наявності у кваліфікованих фахівців як компетенції, так і компетентності. 3'ясовано сутність компетентнісного підходу в рамках

Болонської угоди. Виокремлені особливо значущі принщипи формування культурологічної

компетентності майбутніх економістів для досягнення позитивного результату. Обтрунтовано необхідність створення іншомовної культурологічної компетентності з метою покращення принципів організачії навчального процесу в економічних ВНЗ.

Ключові слова: культурологічна компетентність, гуманізачія навчання, професійне самовизначення особистості, трансляція культур, використання сучасних педагогічних підходів, дворівнева система вищої освіти, проблема іншомовної культурологічної компетентності, культуропровідність, удосконалення змісту навчальних дисщиплін.

Проблема культурологічної підготовки майбутнього фахівця, або так званої креативної підготовки, розроблялася І. Лакатосом, Д. Пойя. На необхідність культурно-творчого виховання спеціаліста неодноразово вказував П. Капіца, який був за фахом інженером і вся діяльність якого є яскравим прикладом реалізації високої творчої культури. Ця проблема розглядається також у теоретичних працях Т. Завершинської, А. Комарової, О. Шевнюк, у дослідженнях О. Коротковського, А. Нікітіна, Т. Синецької, методологічних статтях Л. Кадцина, Н. Крилової, О. Половинкіна.

Аналіз основних досліджень і публікацій. Проблемі гуманізації навчання студентів технічного фаху в процесі вивчення дисциплін гуманітарного циклу присвятили свої дослідження І. Ковалинська, О. Коломієць, А. Кочубей, С. Цимбрило та ін. Значна кількість провідних фахівців досліджували аспекти технічної освіти (В. Данилова, С. Операйло, О. Русанова, П. Стефаненко). Проблему ціннісних орієнтацій на творчу самореалізацію спеціаліста висвітлено у працях С. Гончаренка. Загальнолюдські, національно орієнтовані цінності та цінності сучасного світу досліджено в роботах В. Бабака, С. Лузік. Наукові засади організації виховної роботи обгрунтовані в дослідженнях відомих учених I. Беха, I. Зязюна, А. Капської, С. Карпенчук, Б. Ліхачова, Н. Ничкало, Д. Чернілевського [1: 14-15].

Наявність компетентності визначає можливість і здатність здійснювати професійну діяльність, а привласнення кваліфікації дає на це право. Таким чином, кваліфікація фахівця в ідеалі означає наявність i компетенції, і компетентності. Кваліфікація являє собою об'єктивовану, а компетентність суб'єктивовану форму виявлення професіоналізму. Ми знаємо, що кваліфікація, як і компетенція, присвоюються, вони існують формально, відчужено від безпосереднього носія. Навпаки, компетентність це персоніфікована компетенція, "людина в професії" [2: 3-4].

Період отримання професійної освіти бакалавра стає часом активного професійного самовизначення особистості, на необхідність якого вказують багато дослідників (Є. Бондаревська, І. Ісаєв, Н. Сергєєв, В. Сластьонін, Е. Шиянов та ін.). Саме професійне самовизначення дозволяє забезпечити молодій людині мобільність і готовність до безперервної самоосвіти, здатність адаптуватися до мінливої ситуації в соціальному середовищі і вирішувати нові професійні завдання. Однак в системі вищої освіти цілеспрямоване створення умов для професійного самовизначення здійснюється в основному під час вступу і на момент працевлаштування [3: 111].

Компетентнісний підхід в рамках Болонської угоди визначає необхідність освоєння випускниками вищої школи - бакалаврами, магістрами універсальних компетенцій, які дозволять студентам стати мобільними в сучасному світі, вибирати траєкторії свого професійного зростання, знаходити своє місце в освітньому середовищі для творчої самореалізації. Проблема професійного самовизначення студентів бакалавру в умовах переходу на дворівневу систему вищої освіти знаходиться в центрі уваги педагогічної громадськості не тільки в нашій країні, а й за кордоном [3: 111-112].

Згідно 3 теорією запропонованою Є. Ляховичем - гуманізація освіти означає глобалізацію в трансляції культур. При цьому способи і зміст трансляції повинні бути зорієнтовані на сучасне досягнення загальнолюдської духовності, інтелекту й моральності. У свою чергу, соціалізація людини в межах загальноосвітнього процесу повинна бути спрямована на пошук і реалізацію нових способів розкриття й формування його індивідуальних можливостей [4: 15-23]. 
Оскільки вищий заклад освіти є лише ланкою в системі соціальних інститутів, які формують культуру майбутнього спеціаліста, реформування вищої технічної освіти розглядається як багатоаспектна проблема, що має важливе соціальне й наукове значення і потребує нового педагогічного осмислення, використання сучасних педагогічних підходів і забезпечення гуманітарного впливу на індивідуальний розвиток кожного студента [1: 16-17].

У процесі навчання у вузі у студентів відбувається узгодження своїх бажань, можливостей, орієнтацій 3 умовами та вимогами суспільства. Професійна підготовка у ВНЗ визначає аспект професійного самовизначення студентів - планування своєї майбутньої професійної кар'єри. Важливо створювати умови в процесі навчання у вузі, що сприяють безперервному особистісному зростанню кожного студента, формуванню професійних компетенцій і особистісних якостей, затребуваних ринком праці. У цих умовах реалізація дворівневої системи вищої освіти "бакалаврат - магістратура" дозволить студенту спробувати себе в цілому ряді областей знань, озирнутися і вирішити, чим йому займатися в житті [3: 112].

Обов’язковою складовою професійної компетентності майбутніх фахівців $\epsilon$ культурологічна компетентність. Остання передбачає усвідомлення мови як форми вираження національної культури, взаємозв'язку мови та історії українського народу, національно-культурної специфіки української мови та української мовної поведінки, формування мовної картини світу, оволодіння національномаркованими одиницями мови, українським мовним етикетом, культурою міжнаціонального спілкування [5].

Культурологічний підхід до організації освітнього процесу у вищому навчальному закладі на початку третього тисячоліття слід розглядати на основі єдності широких фундаментальних і глибоко систематизованих спеціальних знань. Він повинен забезпечити оволодіння основами правової,політичної, естетичної, професійної культури, бачення перспектив розвитку різних галузей знань, навичок наукової організації дослідження і впровадження їх у свою майбутню професійно-творчу діяльність, де головним є доцільність, справедливість, гармонія, краса, досконалість [6: 189-191].

Як стверджує провідний фахівець у галузі вищої технічної освіти Д. Чернілевський, стратегічними напрямами реорганізації освіти є: забезпечення нового рівня якості підготовки фахівців і формування гнучкої системи підготовки кадрів, які задовольнятимуть сучасні потреби суспільства у фахівцях із швидкою адаптацією до змінних умов професійної діяльності, тобто здатність молодих фахівців до розширення і поповнення знань [7].

Мета статті полягає у дослідженні і створенні тих передумов, якими необхідно забезпечити студентів для формування і розвитку культурологічної компетентності майбутніх економістів.

Виклад основного матеріалу. У процесі проектування змісту технічної освіти слід враховувати сучасні потреби та вимоги, що нададуть процесу навчання та виховання цілеспрямований, системний характер для досягнення вищеназваної мети. Одним із провідних чинників відбору змісту підготовки спеціалістів є синтезування професійних і гуманітарних знань та взаємозв'язок перспектив розвитку системи освіти, виробництва, техніки, праці, ринку кваліфікованих кадрів і культури.

Кожному етапу розвитку суспільства, як зазначає Н. Ничкало, притаманні свої соціально-економічні та науково-технічні проблеми. Їхнє розв'язання потребує нових підходів, що враховують динаміку змін у життєдіяльності різних соціальних систем [8: 9-22].

Вищезазначене передбачає обгрунтування наукових підходів, педагогічних умов, принципів, розробки моделі і способів проектування системи культурологічної підготовки майбутніх економістів у процесі вивчення гуманітарних дисциплін у вищих економічних навчальних закладах. Саме такий підхід може забезпечити високий рівень сформованості культурологічної компетентності випускників вишів.

Формування культурологічно компетентного економіста має бути закладено у проект його професійної підготовки, побудований на засадах системності, послідовності, відповідності особливостям професійної діяльності.

Проблему іншомовної культурологічної компетентності майбутніх фахівців бізнес-сфери розглядала у своїх роботах І. Іванова. Культуровідповідність, на думку вченої, є важливою вимогою до змісту навчання іншомовного спілкування [9].

С. Дичковський розглядає загальні напрямки розв'язання питань культурологічної підготовки фахівців у вищих навчальних технічних закладах, що є складовою педагогічної системи вищої освіти, яка, у свою чергу, базується і здійснюється на загальнопедагогічних принципах навчання й виховання. Культурологічна підготовка, на думку вченого, є важливою складовою процесу професійної підготовки майбутнього інженера. Вона є системотвірним фактором процесу підготовки студентів вищих технічних закладів освіти, наскрізною ланкою, яка пронизує кожен її компонент [10].

Формування культурологічної компетентності відбувається в спеціально організованому навчальновиховному процесі вищого навчального закладу. Успішний перебіг педагогічного процесу залежить від принципів його організації. Відомо, що зміст навчання визначають навчальний план та робочі програми дисципліни [1: 95-96]. 
Проектування педагогічних умов формування культурологічної компетентності майбутніх фахівців у процесі вивчення гуманітарних дисциплін створює основу для теоретичного моделювання технології цього процесу, результатом чого є вдосконалення існуючих і запровадження нових навчально-виховних систем, форм і засобів, спрямованих на ефективне вирішення питань формування професійної компетентності [1: 93-94].

Педагогічні умови формування культурологічної компетентності майбутніх економістів у процесі вивчення гуманітарних дисциплін дають можливість вирішити такі основні завдання: виявити сукупність зв'язків, відношень, закономірностей, що визначають головні риси та тенденції процесу формування культурологічної компетентності майбутніх спеціалістів економічної галузі; визначити зміст, технології, форми та методи навчання майбутніх економістів i набуття ними особистісних якостей, що характеризують рівень сформованості культурологічної компетентності та готовності до реалізації професійної компетенції у практичній діяльності; оцінити ефективність існуючих і перспективи створення нових форм і методів формування культурологічної компетентності майбутніх економістів у процесі вивчення гуманітарних дисциплін.

Висновки. Отже, у контексті завдань дослідження аналіз систем принципів,запропонованих різними вченими дозволив нам виокремити ті, які вважаємо особливо значущими для досягнення позитивного результату в процесі формування культурологічної компетентності майбутніх економістів. До таких віднесемо:

1) Принцип професійної спрямованості, який дозволяє зосередити увагу студентів на майбутній професійній діяльності за допомогою створення ситуацій професійного інженерно-енергетичного спрямування.

2) Принцип науковості, завдяки якому зміст культурологічної освіти забезпечує об'єктивність наукових фактів, понять, законів, теорій усіх основних тем навчального предмета. Реалізуючи цей принцип, викладач та студенти інформують один одного про нові досягнення в науці, техніці, культурі України та іншомовних країн, мова яких вивчається. Ця інформація подається у формі повідомлень іноземною мовою та пов'язується з системою знань, умінь та навичок, здобутих у процесі навчання гуманітарних дисциплін.

3) Принцип доступності навчання передбачає відповідність змісту, характеру й обсягу навчального матеріалу, який вивчається, віковим особливостям і рівню підготовки студентів-енергетиків. Зміст культурологічного матеріалу повинен ускладнюватися згідно з пізнавальними можливостями та рівнем знань групи.

4) Принцип систематичності й послідовності вимагає, щоб знання, уміння і навички формувались системно. 3 цією метою був розроблений авторський спецкурс із формування культурологічної компетентності, де кожний елемент навчального матеріалу логічно пов'язувався з іншим, а нові знання базувались на здобутих раніше і створювали підгрунтя для засвоєння наступних.

5) Принцип міцності вимагає, щоб знання, уміння, навички,світоглядні та інші ідеї були усвідомлені, добре засвоєні й тривалий час зберігалися у пам'яті. Для реалізації цього принципу обрано систему тестів за міжнародними стандартами STANAG-6001, які студенти виконують під час культурологічної мовної підготовки. Це сприяє процесам глибокого сприймання, осмислення і запам'ятовування навчального матеріалу, а також його повторення та систематизації.

6) Принцип наочності навчання вимагає залучення до сприймання всіх органів чуття студента, передбачає використання натуральних, зображальних, схематичних, аудіовізуальних (звуконаглядних) $\mathrm{i}$ словесно-образних (художніх образів) наочних засобів навчання.

7) Принцип інтенсивності передбачає активну та інтенсивну участь студентів економічних спеціальностей у різних видах діяльності під час занять завдяки інноваційним методикам викладання в процесі вивчення гуманітарних дисциплін, які мають культурологічну спрямованість.

8) Принцип зв'язку з практичною діяльністю, який допомагає зрозуміти студентам значення теорії в житті, проаналізувати варіанти застосування теоретичних знань для виконання практичних завдань, зокрема таких, як проблеми економіки сучасності [8: 95-96].

Тому 3 метою досягнення вищеназваної мети слід створити передумови, що необхідні для формування і розвитку культурологічної компетентності майбутніх економістів. А саме: необхідно удосконалити зміст навчальних дисциплін, таких як "Культурологія", "Історія України", "Іноземна мова", що вимагає розробки експериментальних інтегрованих навчальних спецкурсів.

\section{СПИСОК ВИКОРИСТАНИХ ДЖЕРЕЛ ТА ЛІТЕРАТУРИ}

1. Федорцова О. Г. Формування культурологічної компетентності майбутніх інженерів-енергетиків у процесі вивчення гуманітарних дисциплін : дис.... кандидата пед. наук : 13.00 .04 / Федорцова Олена Григорівна. Житомир, 2016. - $311 \mathrm{c.}$

2. Артамонова Е. И. Инновационная компетентность в становлении профессионализма будущего педагога / Е. И. Артамонова // Материалы Международной научной конференции "Профессионализм педагога : 
сущность, содержание, перспективы развития" (г. Москва, 12-14 марта 2014 г.) - М. МАНПО. - Ярославль : Ремдер. 2014. - 712 c.

3. Егорова О.Л. Некоторые аспекты профессионального самоопределения студентов бакалавриата / О. Л. Егорова// Материалы Международной научной конференции "Профессионализм педагога: сущность, содержание, перспективы развития" (г. Москва,12-14 марта 2014 г.) - М.МАНПО. - Ярославль : Ремдер. $2014-712 \mathrm{c}$.

4. Ляхович Е. С. Личность и культура / Е. С. Ляхович // Вестник высшей школы. - 1991. - № 3. - С. 15-23.

5. Картатова Ю. К. Професійна компетентність учителя української мови та літератури як педагогічна категорія [Електронний ресурс] / Ю. К. Картатова - $2014 . \quad$ - Режим доступу : ttp://www.kspu.kr.ua/ua/ntmd/konferentsiy/2-mizhnarodna-internet-konferentsiya-2014/section-4-5-6.

6. Хомич Л. О. Загальнокультурний розвиток особистості у педагогічній теорії А. С. Макаренка / Л. О. Хомич // Матеріали Міжнародної науково-практичної конференції "Педагогіка А. С. Макаренка в полікультурному освітньому просторі", присвяченої 125-й річниці з дня народження А. С. Макаренка (м. Полтава, 12-14 березня 2013 року) / За заг.ред. проф. М. В. Гриньової. - Полтава, 2013. - С. 189-191.

7. Чернілевський Д. В. Педагогіка вищої школи / [за ред. Д. В. Чернілевського]. - Вінниця : АМСКП, Глобус Прес, 2010. - 408 c.

8. Ничкало Н. Г. Неперервна професійна освіта як філософська та педагогічна категорія / Н. Г. Ничкало // Неперервна професійна освіта : теорія і практика. - 2001. - Вип. 1. - 212 с.

9. Іванова І. В. Діагностування сформованості професійної іншомовної культурологічної компетентності майбутніх фахівців бізнес-сфери / I. В. Іванова // Наукові записки. Серія "Психолого-педагогічні науки" (Ніжинський державний університет імені Миколи Гоголя) / [за заг. ред.проф. Є. І. Коваленко]. - Ніжин : Видавництво НДУ ім. М. Гоголя, 2009. -№ 3. - 313 с.

10. Дичковський С. I. Педагогічні засади культурологічної підготовки майбутніх інженерів засобами дистанційного навчання : автореф. дис. на здобуття наук. ступеня канд. пед. наук : спец. 13.00 .04 "Теорія i методика професійної освіти" / С. І. Дичковський. - К., 2009. - 21 с.

\section{REFERENCES (TRANSLATED \& TRANSLITERATED)}

1. Fedortsova O. H. Formuvannшa kul'turolohichnoi kompetentnosti maybutnikh inzheneriv-enerhetykiv $\mathrm{u}$ protsesi vyvchennia humanitarnykh dystsyplin [Future Energy Engineers' Cultural Competence Formation in the Process of Studying Humanitarian Disciplines] :dys. ... kandydata ped. nauk: 13.00.04 / Fedortsova Olena Hryhorivna. Zhytomyr, 2016. - $311 \mathrm{~s}$.

2. Artamonova E. I. Innovacionnaia kompetentnost' v stanovlenii professionalizma budushhego pedagoga [Innovative Competence in the Development of Professionalism of the Future Teacher] / E. I. Artamonova // Materialy Mezhdunarodnoi nauchnoi konferentsii "Professionalizm pedagoga: sushhnost', soderzhanie, perspektivy razvitiia" (g. Moskva,12-14 marta 2014 g.) [Materials of the International Scientific Conference "Teacher's Professionalism: Essence, Content, Development Prospects"]. - M. MANPO. - Jaroslavl' : Remder. 2014 - 712 s.

3. Egorova O. L. Nekotoryie aspekty professional'nogo samoopredeleniia studentov bakalavriata [Some Aspects of Professional Self-Determination of Undergraduate Students] / O. L. Egorova // Materialy Mezhdunarodnoi nauchnoi konferentsii "Professionalizm pedagoga : sushhnost', soderzhanie, perspektivy razvitiia" (g. Moskva,12-14 marta 2014 g.) [Materials of the International Scientific Conference "Educator's Professionalism: Essence, Content, Development Prospects"]. - M. MANPO. - Jaroslavl': Remder. 2014 - 712 s.

4. Liahovich E. S. Lichnost' i kul'tura [Personality and Culture] / E. S. Liahovich // Vestnik vysshei shkoly [Journal of Higher School]. - 1991. - № 3. - S. 15-23.

5. Kartatova Yu. K. Profesiina kompetentnist' uchytelia ukrayins'koi movy ta literatury yak pedahohichna katehoriya [Professional Competence of the Teacher of the Ukrainian Language and Literature as a Pedagogical Category]. [Elektronnyi resurs] / Yu. K. Kartatova. - 2014. - Rezhym dostupu //www.kspu.kr.ua/ua/ntmd/konferentsiy/2mizhnarodna-internet-konferentsiya-2014/section-4-5-

6. Khomych L. O. Zahal'nokul'turnyi rozvytok osobystosti u pedahohichnii teorii A. S. Makarenka [General Cultural Development of Personality in Pedagogical Theory of A. S. Makarenko]/ L. O. Khomych // Materialy Mizhnarodnoi naukovo-praktychnoi konferentsii "Pedahohika A. S. Makarenka v polikul'turnomu osvitn'omu prostori", prysvyachenoyi $125-\mathrm{y}$ richnytsi z dnia narodzhennia A. S. Makarenka (m. Poltava, 12-14 bereznia 2013 roku) [Materials of the International Scientific and Practical Conference " A. S. Makarenko's Pedagogy in a Multicultural Educational Space " dedicated to the 125th Anniversary of A. S. Makarenko's the Birth (Poltava, March 12-14, 2013)] / Za zah.red. prof. M. V. Hryn'ovoi - Poltava, 2013. - S. 189-191.

7. Chernilevs'kyy D. V. Pedahohika vyshchoi shkoly [Pedagogics of Higher Education]/ [za red. D. V. Chernilevs'koho]. - Vinnytsia : AMSKP, Hlobus - Pres, 2010. - 408 s.

8. Nychkalo N. H. Neperervna profesiina osvita yak filosofs'ka ta pedahohichna katehoriya [Continuous Vocational Education as a Philosophical and Pedagogical Category] / N. H. Nychkalo // Neperervna profesiina osvita : teoriia i praktyka [Continuing Professional Education: Theory and Practice]. - 2001. - Vyp. 1. - $212 \mathrm{c}$.

9. Ivanova T. V. Diahnostuvannia sformovanosti profesiinoi inshomovnoi kul'turolohichnoi kompetentnosti maybutnikh fakhivtsiv biznes-sfery [Diagnosis of the Formation of Professional Foreign Language Cultural Competence of Future Professionals in the Business Sphere] / I. V. Ivanova // Naukovi zapysky. Seriia "Psykholohopedahohichni nauky" (Nizhyns'kyi derzhavnyi universytet imeni Mykoly Hoholia) [Proceedings. Series " Psychological and Pedagogical Sciences " (Nizhyn State University named after Mykola Gogol)] / [za zah. red. prof. Ye. I. Kovalenko]. - Nizhyn : Vydavnytstvo NDU im. M. Hoholya, 2009. -№ 3. - 313 s.

10. Dychkovs'kyi S. I. Pedahohichni zasady kul'turolohichnoi pidhotovky maybutnikh inzheneriv zasobamy dystantsiinoho navchannia [Pedagogical Bases of Future Engineers' Culturological Preparation by Means of 
Distance Learning] : avtoref. dys. na zdobuttia nauk. stupenia kand. ped. nauk : spets. 13.00.04 "Teoriia i metodyka profesiinoi osvity" / S. I. Dychkovs'kyi. - K., 2009. - 21 s.

\section{Федорцова Е. Г. Проблема формирования культурологической компетентности студентов бакалавриата - будущих экономистов.}

В статье представлень предпосылки формирования культурологической компетентности студентов бакалавриата - будущих экономистов. Подчеркивается необходимость наличия у квалифицированных специалистов, как компетенции, так и компетентности. Выяснено сущность компетентностного подхода в рамках Болонского согламения. Выделены особо значимые принципы формирования

культурологической компетентности будущих экономистов для достижения положительного результата. Обоснована необходимость создания иноязычной культурологической компетентности с целью улучшения принцииов организации учебного прочесса в экономических вузах.

Ключевые слова: культурологическая компетентность, гуманизация обучения, профессиональное самоопределение личности, трансляция культур, использование современных педагогических подходов, двухуровневая система высшего образования, проблема иноязычной культурологической компетентности, совершенствование содержания учебных дисииплин.

\section{Fedortsova E. H. The Problem of Forming Undergraduate Students' - Future Economists' Cultural Competence.}

The article presents the preconditions of undergraduate students' - future economists' cultural competence formation. The signs of future economic specialty specialists' competence are singled out. It is emphasized the necessity of having qualified specialists in competence. The essence of the competent approach within the framework of the Bologna Agreement is revealed. Particularly significant principles of forming the cultural competence of future economists are set out to achieve a positive result. Directions are given for creating a foreign-language cultural competence in order to improve the principles of organizing the educational process in economic universities.

It is this approach that can ensure future specialists' high level cultural competence while studying.

The author points out one of the main factors in the content training selection of the specialists is the synthesis of professional and humanitarian knowledge and the interconnection of prospects of the education system as well as production, technology, labour, market of skilled personnel and culture.

Formation of culturologically competent economists must be incorporated into the project of their professional training built on the principles of systemicity, consistency, compliance with the peculiarities of professional activity.

Since culturological competence formation takes place in a specially organized educational process of a higher educational establishment the successful course of the pedagogical process depends on the principles of its organization.

Key words: cultural competence, humanization of learning, professional self-determination of personality, cultures broadcast, use of modern pedagogical approaches, two-tier system of higher education, foreign cultural competence problem, cultural conductivity, educational curricula improvement. 